\title{
24. Demogrāfiskās politikas izaicinājumi un pasākumi dzimstības veicināšanai
}

\author{
Līga Āboliṇa, Ilmārs Mežs, Ilze Mileiko
}

\section{Demogrāfiskā politika un tautas ataudze}

Demogrāfiskās politikas saturu, uzdevumus un pasākumus ir skaidrojuši gan speciālisti, gan starptautiskas, valstiskas un nevalstiskas institūcijas (United Nations, 2013). Demogrāfisko terminu skaidrojošajā vārdnīcā (Zvidriņš, 2001, 26) demogrāfijas politika skatīta kā mērḳtiecīga darbība, lai ietekmētu iedzīvotāju kustību. Dažādu valstu pieredze demogrāfiskās politikas realizācijā atšķiras. Strauji augošās sabiedrībās demogrāfiskās politikas mērḳis bieži vien ir iedzīvotāju skaita pieauguma ierobežošana, kamēr depopulācijas situācijās tiek meklēti risinājumi iedzīvotāju skaita pieauguma veicināšanai. Demogrāfiskās politikas izaicinājums sabiedrības ilgtspējas nodrošināšanai Latvijā ir dzimstības rādītāju palielināšana, sasniedzot vismaz vidējos rādītājus ES. Šajā nodaḷā galvenokārt ir apskatīti demogrāfiskās politikas instrumenti saistībā ar tautas ataudzes veicināšanu un depopulācijas ierobežošanu.

"Latvijas ilgtspējīgas attīstības stratēǵijas līdz 2030. gadam” jeb projekta “Latvija 2030" uzraudzības ziņojumā uzsvērts, ka dzimstības rādītāji ir kritiskā situācijā, par cēloni minot ne tik daudz valsts ekonomisko stāvokli, cik nepietiekamu ekonomiskās drošības sajūtu (PKC, 2012, 18). 90. gados dzimstības samazinājuma apstākḷos dzimušie bērni pašlaik ir sasnieguši reproduktīvo vecumu, un viņu nepietiekamais skaits tautas ataudzes nodrošināšanai ietekmēs arī dzimušo bērnu skaitu Latvijā nākotnē. Tāpēc nepieciešams veidot aktīvu demogrāfisko politiku. Citu valstu pieredze liecina, ka, veidojot pārdomātu demogrāfisko politiku, iespējams panākt dzimstības pieaugumu. Piemēram, Igaunijā 2003. gadā tika ieviesti demogrāfiskās politikas pasākumi atbalstam ǵimenēm ar bērniem, tās rezultātā dzimušo skaits palielinājās gandrīz par 1/3 (Mežs, 2014). Igaunijā tika definēti demogrāfiskās politikas mērḳi, kas ietvēra virkni atbalsta pasākumu ğimenēm ar bērniem. Kā galvenā Igaunijas panākumu atslēga dzimstības līmeņa paaugstināšanai tiek minēta drošības palielināšanās dažādos aspektos (Uibu, 2013, 6). Arī Latvijā veiktajā pētījumā (Eglīte u. c., 2013) ekonomiskā drošība, kā arī drošỉba attiecībās un citās dzìves 
jomās ir skatīta kā priekšnoteikums, lai ǵimenē plānotu tautas ataudzei pietiekamu bērnu skaitu.

\section{Demogrāfiskās politikas mērḳi un instrumenti Latvijā}

Demogrāfisko rādītāju uzlabošanās ir izvirzìta par mērḳi "Latvijas Nacionālajā attīstības plānā 2014.-2020. gadam". To saista ar 1) reproduktīvās veselības uzlabošanos; 2) abortu skaita samazināšanos; 3) labākām iespējām saskaņot darba un ǵimenes dzīvi, arī ar bērnudārzu pieejamības uzlabošanos; 4) motivējošu atbalstu ǵimenēm; 5) atbalstu ǵimenēm krīzes situācijās (Latvijas Nacionālais attīstības plāns 2014.-2020. gadam). Dzimstības paaugstināšana minētajā plānā ir skatīta kā priekšnoteikums latviešu tautas pastāvēšanai nākotnē. Arī plānošanas dokumentā "Latvijas ilgtspējīgas attīstības stratēǵija līdz 2030. gadam" dzimstība skatīta valsts ilgtermiņa attīstības kontekstā. Šajā dokumentā atzīts, ka ilgtermiṇā nebūs viegli uzturēt sociālo līdzekḷu pārdali par labu dzimstības veicināšanai. Tāpēc tiek ieteikts meklēt arī citus veidus atbalstam vecākiem ar bērniem, kā galveno minot darba un ǵimenes dzīves saskaņošanu.

Ģimenes valsts politikas pamatnostādnēs 2011.-2017. gadam ğimene skatīta kā pamats valsts demogrāfiskās attīstības stabilitātei. Dokumentā teikts, ka valsts atbalsta ğimeṇu veidošanos un to stabilitāti, atbalsta vecākus krīzes situācijās, sekmē dzimstību, stiprinot laulību un paaugstinot laulības vērtību sabiedrībā. Tādējādi tiek uzsvērts atbalsts partnerībai, kas balstās uz laulību.

Iepriekš minētie politikas dokumenti aktualizē zemos dzimstības rādītājus kā valstisku problēmu. Ar dzimstības veicināšanu ir saistīit vairāki rīcībpolitikas virzieni: ğimenes ienākumu līmeņa saglabāšana, piedzimstot bērnam; darba, gimenes un personiskās dzìves saskaņošana; dzimumu līdztiesības veicināšana; reproduktīvās veselības uzlabošana; atbalsts nabadzības mazināšanai daudzbērnu gímenēs un vientulajiem vecākiem. Šie virzieni turpmāk tekstā apskatìti detalizētāk.

Ģimeņu ienākumu līmeņa saglabāšana, tajās ienākot bērnam, ir būtisks dzimstības veicināšanas politikas virziens. Tas ietver dažādus atbalsta veidus pirms un pēc dzemdībām, kurus var saņemt gan gimenes, gan sievietes, piemēram, grūtniecības un pēcdzemdību perioda apmaksātu atvaḷinājumu 56 vai noteiktos gadỉjumos 70 dienas pirms un 56 (70) dienas pēc dzemdībām, bērnu kopšanas pabalstu laika posmā, kamēr vecāks nestrādā un aprūpē savu bērnu. Pētijumā "Tautas ataudzi ietekmējošo faktoru izpēte" norādīts, ka speciāls monetārs atbalsts gímenēm vairāk tiek koncentrēts uz ğimenēm bērna pirmajos gados, vēlāk būtiski samazinoties un sniedzot mērkiētu atbalstu tikai trūcīgajām ǵimenēm. Atbalsta pasākumus, kas iekḷauti ǵimenes ienākuma līmeņa saglabāšanai, cilvēki vērtē pozitīivi, satraucoties nevis par atbalsta apjomu, bet likumdošanas izmaiņām, kas rada nedrošību, vecākiem ilgtermiṇā plānojot 
grūtniecību (Eglīte u. c., 2013). Latvijas demogrāfiskās atveseḷošanās programmā Latvijas simtgadei "Māras solis" ir iekḷauti mērḳi kāpināt gan vecāku, gan ǵimenes valsts pabalstu, mainot to apjomu atkarībā no bērnu skaita gimenē. Problēma ir atrast līdzekḷus šādam pabalstu apjoma pieaugumam.

Darba, ğimenes un personiskās dzīves līdzsvarošana ir rīcībpolitikas virziens, kas tiek saistīts ar bērnu uzraudzības pakalpojumu nodrošināšanu, piemēram, mazinot rindas uz bērnudārzu un līdzfinansējot alternatīvus bērnu uzraudzības pakalpojumus, ja vieta pašvaldības bērnudārzos nav pieejama. Programmā "Māras solis" norādīts, ka pirmsskolas vecuma bērnu izglìīibai un pieskatǐšanai var tikt lietots princips "nauda seko bērnam", l̦aujot vecākiem brīvu izvēli izmantot dažādas bērnu pieskatīšanas formas.

Savienot darba un ǵimenes dzivi palīdz Darba likumā iekḷautās normas, kas ierobežo darba devēju tiesības atlaist sievietes grūtniecības laikā un nosaka pienākumu saglabāt darbiniekam darbavietu pēc bērnu kopšanas atvaḷinājuma, sniedz tiesības n,emt slimības kopšanas atvalinājumu, bērnam saslimstot, u. c. Aktivitāte, kas veicina darba devēja iesaisti ǵimenes un darba dzīves līdzsvarošanai, ir "ǵimenei draudzīgs komersants", kur uzṇēmumi gimeni iekḷauj kā vienu no savas korporatīvās kultūras vērtībām (biedrība "Korporatīvās ilgtspējas un attīstības institūts").

Dzimuma līdztiesība parasti netiek iekḷauta politikas dokumentos saistībā ar dzimstību. Dzimumu līdztiesības politikā būtiskas problēmas ir vardarbības pret sievieti izskaušana, nevienlīdzība darba tirgū, dzimumu segregācija profesiju izvēēē, kas rada pastāvīgas atškirības darba samaksā (Rastrigina, 2015, 4). Visi nosauktie aspekti ietekmē sieviešu drošîbas sajūtu un dzīves kvalitāti, kas netieši var iespaidot arī dzimstību. Dzimumu līdztiesības veicināšana nodrošina arī sabiedrības izpratni par abu vecāku algotā un neapmaksātā darba, ko veic mājās, vienlīdzīgu dalīšanu. Pētījumā par šķiršanos, kas veikts VPP projekta ietvaros (Putniņa u. c., 2015), norādīts, ka nevienlīdzīga pienākumu sadale mājsaimniecībās ir viens no iemesliem partnerattiecību izjukšanai. Tas liek domāt, ka šis politikas virziens var tik attīstīts, veicinot ǵimeņu stabilitāti Latvijā. Proti, izpratne par līdzīgu pienākumu sadalījumu ǵimenēs ar bērniem mazina spriedzi attiecībās, kas var novest pie šķiršanās. Laulību šķirot, tēviem nereti tiek atvēlēta iespēja apciemot savus bērnus nedēḷas nogalēs, liedzot regulāru saskarsmi. Tas var būtiski ietekmēt bērnu un tēvu savstarpējās attiecības, kā arī "brīvdienu tēva" loma ir saistìta ar izdevumiem, tādēḷ bērnu saskarsme ar trūcīgiem tēviem ir apgrūtināta (Sedlenieks u. c., 2017).

Dzimumu līdztiesība vienlīdz negatīvi ietekmē abu dzimumu pārstāvjus. Tāpēc abiem vecākiem jāḷauj realizêt likumā noteikto kārtību, kas paredz vienādas tiesības un pienākumus bērnu audzināšanā. To var īstenot, tikai veicinot sabiedrības izpratni par dzimumu līdztiesības jautājumiem. Abu vecāku lielāka iesaistīšanās bērnu audzināšanā šķirtajās ğimenēs ḷautu nodrošināt viniem lielākas iespējas darba un ǵimenes dzîves savienošanai, ietekmētu šķirto vecāku 
pieredzi un radītu pārliecību par sevi kā vecāku, kas var ietekmēt bērnu plānošanu nākotnē.

Arī atbalsts pirmā mājokḷa iegādei ir saistīts ar dzimstības veicināšanu, jo galvojuma piešķiršanas nosacijjumos pirmā mājokḷa iegādei ir atbalsta progresivitāte, kas saistīta ar bērnu skaitu gimenē. Publiskajā telpā ir izskanējušas ziņas, ka pašlaik ir apzināti virzieni programmas iespējamajiem uzlabojumiem, paplašinot atbalstu daudzbērnu giimenēm un jaunajām ğimenēm. Valsts attīstības finanšu institūcijas - ALTUM - programmas mājaslapā (https://www.altum.lv) norādīts, ka līdz šim ALTUM pieškīirusi vairāk nekā 3420 galvojumu par kopējo summu 22,4 milj. eiro. No galvojumu kopējā skaita 6\% jeb 354 galvojumi ir piešķirti mājokḷa iegādei ğimenēm ar trim vai vairāk bērniem, $32 \%$ jeb 1776 galvojumi - ǵimenēm ar diviem bērniem, savukārt lielākā daḷa - 62\% jeb 3402 galvojumi piešķirti ǵimenēm ar vienu bērnu. Vidējais piešķirtā galvojuma apmērs ir 6700 eiro.

Reproduktīvā veselība tiek veicināta, nodrošinot bezmaksas veselības aprūpes pakalpojumus grūtniecēm, dzemdības, atbalstu pēcdzemdību periodā, kā arī darbojas neauglības ārstēšanas valsts programma, kas l̦auj saṇemt atbalstu neauglības ārstēšanai. Kā drauds dzimstībai skatìts augstais abortu skaits. Pētījumā secināts, ka augstais abortu skaits var būt saistīts ar nepietiekošām zināšanām par kontracepciju un retu tās lietošanu (Rastrigina u. c., 2015, 4). Paplašinot jauniešu zināšanas par kontracepciju un par atbildīgu tās lietošanu, var samazināt neauglības gadījumus, tātad ilgtermin̦ā pozitīvi ietekmēt dzimstību. Savukārt, ja zināšanu par kontracepciju trūkst, tad bieži vien par dzimstību regulējošu instrumentu tiek izmantots aborts, kas rada riskus veselībai.

Specifisks demogrāfiskās politikas instruments dzimstības kāpināšanai ir atbalsts nabadzības mazināšanai. Analizējot iepriekš veiktos pētījumus, tiek iezīmētas divas specifiskas ğimeņu grupas, kurām nabadzības riski ir augstāki nekā citām: 1) daudzbērnu ǵimenes un 2) vecāki, kas audzina bērnus vieni. Katrai minētajai grupai, kuras ir vairāk pakḷautas nabadzības riskam, ir identificējamas atškirīgas valsts piedāvātā atbalsta stratēgijas, kas raksturotas turpmāk.

Daudzbērnu ǵimenes Bērnu tiesību aizsardzības likumā skatītas kā tādas, kurās ir trīs un vairāk bērnu vecumā līdz 18 gadiem (ja bērni turpina mācīties, tad līdz 24 gadiem). Pētījumā "Izpētes ziņojums: daudzbērnu ğimeṇu situācija mūsdienu Latvijā" (S. Salaka u. c., 2014, 16), aplūkojot ğimenes valsts pabalstu saṇēmēju skaitu, autori secinājuši, ka "Latvijā ir ap 27800 gimenes ar trīs bērniem, apmēram 7800 ǵimenes ar četriem bērniem, gandrīz 3000 gimenes ar pieciem bērniem un 2500 ǵimenes ar sešiem un vairāk bērniem. Tādējādi daudzbērnu ǵimeņu kopējais skaits Latvijā veido vairāk nekā 41 000, ieskaitot visas gimenes ar trīs un vairāk bērniem līdz un pēc bērnu 18 gadu vecuma sasniegšanas". Šajā pētījumā ir problematizēta daudzbērnu ǵimen̦u definēšana (Salaka u. c., 2014, 11). Grūtības saistītas ar mūsdienu realitāti - gimenes tiek škirtas un veidotas jaunas, tajās aug bērni no vairākām laulībām vai izplatīta ir 
kopdzīve nereǵistrētās attiecībās. Turpat tiek analizēts arī daudzbērnu vecāka jautājums, jo vienam vecākam var būt trīs un vairāk bērnu dažādās attiecībās, tomēr viņš var ar tiem nedzīvot kopā un par tiem nerūpēties. Tāpēc, sniedzot valsts atbalstu, būtu jāṇem vērā ne tikai bērnu skaits, bet arī tas, vai vecāks gādā par saviem bērniem.

Daudzbērnu ǵimeņu atbalstam tiek izmantoti vairāki specifiski instrumenti: 1) gimenes valsts pabalsts, par katru nākamo bērnu kāpinot pabalsta apjo$\mathrm{mu}$; 2) atlaide transportlīdzekḷu ekspluatācijas nodoklim vienam transportlīdzeklim; 3) atlaide mājokḷa nekustamā īpašuma nodoklim; 4) specifiski atbalsta pakalpojumi daḷā pašvaldību, kas gan atšķiras atkarībā no pašvaldību turīguma un to vadītāju politiskās izvēles (piemēram, atlaides ēdināšanai skolās un bērnudārzos, interešu izglītībai un pašvaldību transportam). Būtisks valsts atbalsts ir saistìts ar gimenes goda programmas realizāciju, kur finansiāls atbalsts dažādu atlaižu veidā tiek jau realizēts. Pēdējos gados atbalsta kāpināšana daudzbērnu ǵimenēm ir bijusi diezgan konsekventa, mērḳtiecīgi plānojot palielināt atbalstu arī nākotnē. Tas ir pozitīvs signāls vecākiem ar trīs un vairāk bērniem un rada pārliecību, ka daudzbērnu ğimenes tiks atbalstītas arī turpmāk. Pētījuma "Tautas ataudzi ietekmējošo faktoru analīze" datu sekundārā analīze liecina, ka vecāki, kuriem ir bērni ar lielu vecuma starpību, nav apmierināti ar pašreizējo pabalstu kārtību. Ir situācijas, kad ǵimene saņem valsts atbalstu par bērniem, kuri ir vecāki par 18 gadiem un joprojām dzīvo gimenē, bet citi valsts pabalsti vairs nav pieejami. Vecāki uzskata: ja ir izaudzināti vairāk nekā divi bērni, ğimene ir cienīga sañemt atbalstu neatkarīgi no vecāko bērnu vecuma.

Otra grupa, kam nepieciešams atbalsts nabadzības mazināšanai, ir vientul̦ie vecāki. Līga Āboliṇa norāda, ka 2011. gadā nepilno g̣imeņu skaits Latvijā ir gandrīz 1/3 no visām ǵimenēm (Āboliṇa 2016, 5). Šis īpatsvars ir nemainīgi augsts kopš 2000. gada. Vientuḷie vecāki identificēti kā grupa, kura visbiežāk pakḷauta nabadzības un izdegšanas riskam un kurai ir grūtības apvienot darbu ar gimenes dzìvi, jo viens vecāks ir gan naudas pelnītājs, gan bērnu pieskatītājs (Eglīte u. c., 2013). Pārresoru koordinācijas centra ziņojumā "Tautas ataudzi kavējošie faktori” (Kārkliņa, 2016, 6) norādīts, ka 2014. gadā nabadzības riska indekss bērniem, kurus audzina viens pieaugušais, bija 41,1, bet ǵimenes, kur ir divi pieaugušie un trīs vai vairāk bērnu, nabadzības riska indekss bija 27,7. Viena vecāka ǵimenes saikne ar nabadzību identificēta arī citos pētījumos (GFK Custom Research Baltic, 2013; SKDS, 2008). Lai arī grupa ir apzināta, tomēr vientuḷajiem vecākiem kā grupai tiek sniegts tikai viens specifisks atbalsts valsts lìmenī - uzturlīdzekḷu garantiju fonds nodrošina uzturlīdzekḷus valstī noteiktajā minimālo uzturlīdzekḷu apmērā tiem vecākiem, kas vieni audzina savus bērnus (otrs vecāks savu pienākumu nepilda). Šī atbalsta efektivitāte un ietekme nav mērīta. Grupa, kurai trūkt atbalsta, ir viena vecāka bērni jeb tie, kam dzimšanas reǵistrā nav ieraksta par tēvu. Šādi gadījumi ik gadu ir ap 2-3\%. Ja ieraksta par paternitāti nav, bērna aprūpe pilnībā gulstas uz vienīgā 
vecāka pleciem, kamēr netiek noteikta paternitāte (tiesas ceḷā vai labprātīgi). Nav identificēti specifiski atbalsta rīki vientuḷajiem vecākiem pašvaldībās (Eglìte u. c., 2013).

Atbalsta kāpināšana tieši šai grupai ir viens no lielākajiem izaicinājumiem demogrāfijas politikas kontekstā, jo pētījumā "Tautas ataudzi ietekmējošo faktoru izpēte" (Eglìte u. c., 2013) secināts, ka bērnu audzināšanas pieredze ietekmē to, vai vecāks izvēlas radīt nākamos bērnus. Nabadzības, izdegšanas risks, kā arī grūtîbas savienot darba un ǵimenes dzīvi var negatīvi ietekmēt vientuḷo vecāku vēlmi radīt vēl kādu bērnu citā savas dzīves posmā. Atbalsts šai grupai var būt svarīgs dzimstības veicināšanas politikā. Līdz šim atbalsta palielināšana vientuḷajiem vecākiem ir saistīta ar vairākiem faktoriem: 1) ar grūtībām grupu definēt; 2) ar atšķirīgām grupas locekḷu vajadzībām; 3) ar grupas mainīgumu. İstenot atbalsta politiku, kas mērķēta uz vientulajiem vecākiem kā specifisku grupu, apgrūtina fakts, ka grupas noteikšanai valsts kontekstā nav izstrādāta definīcija, jo vairumā gadījumu grupa skatīta kā mainīga un ietvertās pazīmes nav viendabīgas. Definējot vientuḷos vecākus kā grupu, jāskata divi jautājumi: bērnu aprūpes nodrošināšana un ǵimenes apgādāšana. Ja viens cilvēks veic abus pienākumus, viņu var uzskatìt par vientuḷo vecāku. Tomēr ne visos gadỉjumos, ņemot vērā šĩs divas pazīmes, grupas definēšanā ir skaidrs, kurš cilvēks var tikt klasificēts kā vientulais vecāks. Vai viņš ir uzskatāms par vientuḷo vecāku arī tad, ja dzīvo kopā ar bērniem vienā mājsaimniecībā ar vecvecākiem, kuri iesaistās mazbērnu aprūpē. Ar ko atšķiras bērnu aprūpe šķirtam vecākam, kas bērnu audzina viens, salīdzinājumā ar tiem, kuru dzīvesbiedri ilgstoši atrodas ārzemēs un līdz ar to neiesaistās bērnu aprūpē. Runājot par ğimenes apgādāšanu, par vientuḷiem vecākiem var uzskatīt tos, kuri apgādā bērnus vieni, jo otrs vecāks ir miris (tiek saņemts pabalsts no valsts) vai nesniedz finansiālu atbalstu bērnu audzināšanā, proti, uzturlīdzekḷi tiek saṇemti no uzturlīdzekḷu garantijas fonda vai netiek saņemti vispār, jo bērnam nav noteikta paternitāte. Tomēr ir šaubas, vai papildu atbalsts ir sniedzams, ja bērna vecāks, kas nedzīvo ar bērnu, formāli to sniedz, bet palīdzības apjoms neḷauj nodrošināt bērna vajadzības. Šie ir tikai daži apsvērumi, kas apgrūtina vientuḷo vecāku noteikšanu.

Definējot grupu pārāk aptveroši, tā būs l,oti plaša, un līdz ar to vērā ņemamu palīdzību grupai valsts nespēs nodrošināt, bet, definējot to šauri, tā būs iejaukšanās cilvēku privātajā dzīvē un būs nepieciešama liela kontrole, lai mākslīgi nekāpinātu grupas lielumu. Piemēram, Lielbritānijā, sniedzot atbalstu vecākiem, kas bērnus audzina vieni, būtiski pieauga vientuḷo vecāku skaits. Tāpēc, definējot šo grupu, svarīgi ir padziḷināti izpētīt, kā vientuḷos vecākus definē citās valstīs un kā definēšana ietekmē dažādu sociālu pakalpojumu piedāvājumu un lietojumu.

Otra problēma, kas traucē atbalstìt vientuḷos vecākus atbilstoši to vajadzìbām, ir tā, ka vecāki, kas audzina bērnus vieni, nav viendabīga grupa arī pēc 
citām pazīmēm, piemēram, pēc bērnu skaita, nodarbinātības stāvokḷa, dzimuma. SKDS 2008. gadā veiktajā pētījumā identificēts, ka nabadzības risks viena vecāka ǵimenēs būtiski pieaug atkarībā no bērnu skaita, - jo lielāks bērnu skaits, jo augstāks nabadzības risks. Vientuḷie vecāki nav monolīta grupa arī saiknē ar nodarbinātības veidu un darba laika organizāciju. Labklājības ministrijas pētījumā "Elastīga bērnu uzraudzības pakalpojuma nodrošināšana darbiniekiem, kas strādā nestandarta darba laiku"1 (Mileiko u. c., 2017) identificēts, ka vientuḷie vecāki ir specifiska grupa, kam grūtāk saskaņot darba un ğimenes dzīvi, strādājot nestandarta darba laiku, jo, ja darbs jāveic nestandarta darba laikā, bērnu pieskatīšanas pakalpojumi pašvaldībās nav pieejami, bet paši apmaksāt aukles pakalpojumus nevar zemo ienākumu dēḷ. Dažkārt sievietes izvēlējās strādāt nestandarta darba laiku, lai vienlaicīgi nodrošinātu bērnu pieskatīšanu. Pētījumā identificēts, ka dažreiz vientuḷie vecāki atstāj bērnu uz mirkli mājās vienu, jo nav citu risinājumu.

Apvienojot darba dzīvi ar bērnu audzināšanu, saskaņot standarta un nestandarta darba laiku nav vienlīdz viegli, jo standarta darba laikā tiek nodrošināti bērnu pieskatīšanas pakalpojumi, kamēr vientuḷajiem vecākiem, kuri strādā nestandarta darba laiku, līdzvērtīgi bērnu uzraudzības pakalpojumi, kuru izmaksas segtu valsts vai pašvaldības, visā Latvijā nav pieejami. Projekta "Elastīga bērnu uzraudzības pakalpojuma nodrošināšana darbiniekiem, kas strādā nestandarta darba laiku” ietvaros veikts eksperiments trīs pašvaldībās Rīgā, Valmierā un Jelgavā, lai izstrādātu ieteikumus, kā ieviest elastīgus bērnu pieskatīšanas pakalpojumus cilvēkiem ar nestandarta darba laiku. Pakalpojuma ieviešana var veicināt tādu vecāku, kas audzina bērnus vieni un strādā nestandarta darba laiku, spēju līdzsvarot ǵimenes un darba dzīvi, līdz ar to mazinot nabadzības risku un veicinot vientuḷo vecāku nodarbinātību.

Grūtības nodrošināt specifiskus pakalpojums vientuḷajiem vecākiem var būt saistītas arī ar šìs grupas mainību. Tomēr grūtības, kas saistītas ar vientuḷā vecāka statusa noteikšanu, nav nepārvaramas. Ir jāturpina detalizēti pētīt faktorus, kas ietekmē dzimstību.

\section{Dzimstību veicinošu atbalsta pasākumu iniciatīvas kopš 2013. gada}

Latvijā atbalsta pasākumi ǵimenēm ar bērniem tiek pilnveidoti kopš 2013. gada. Tos ir sekmējuši speciālistu ieteikumi un diskusijas Demogrāfisko lietu centrā, Demogrāfisko lietu padomē un Saeimas Demogrāfijas lietu apakškomisijā. Plašākā sabiedrībā politikas uzlabojumu iniciatīvas ieguva atpazīstamību kā "demogrāfijas ultimāti". Aplēses liecina, ka demogrāfijas atbalsta uzlabojumu monetārā vērtība 2013.-2018. gada valsts budžetā sasniedz

Nestandarta darba laiks ietver agra rīta stundas, vēlas vakara stundas un nakts stundas. 
ap 200 milj. eiro. Atbalstu ir paredzēts turpināt arī nākamajos gados. Apjoma ziņā papildu piešķīrumi ǵimeņu atbalstam valsts budžetā ieņem trešo vietu aiz valsts aizsardzības un veselības aprūpes. 2008. gadā Latvija atvēlēja tikai 0,7\% no IKP ǵimeṇu un bērnu atbalstam, ieņemot pēdējo vietu starp ES dalībvalstīm, bet 2016. gadā atbalsts palielinājās līdz 1,2\% no IKP un Latvija pakāpās par septiņām vietām (Eurostat, 2018). Atbalstu ir paredzēts turpināt. Bērna kopšanas pabalsts (jeb t. s. māmiņalga neapdrošinātām māmiņām) pakāpeniski ir palielināts no 50 latiem (71 eiro) līdz 171 eiro. Turklāt šì atbalsta periods ir pagarināts no viena gada līdz pusotram gadam. Arī strādājošās māmiñas vai tēvi ilgāk saņem atbalstu, turklāt viniiem ir iespējas izvēlēties, vai atbalstu saņemt gadu vai pusotru gadu, attiecīgi plānojot savu atgriešanos darbā. Izvēloties pabalstu viena gada garumā, tā apjoms ir $60 \%$ no iepriekšējās algas, bet pusotra gada garumā $-43,75 \%$ no iepriekšējās algas. Bērnu kopšanas pabalsts tiek izmaksāts arī tiem, kuri jau saņem vecāku pabalstu.

Ģimenes valsts pabalsts ir divkāršots par otro bērnu, trīskāršots par trešo bērnu un 4,4 reizes lielāks par ceturto un nākamajiem bērniem. 2012. gadā māminasas ik mēnesi saṇēma 8 latus (11,38 eiro) par katru bērnu, bet tagad ir panākts būtisks pieaugums par visiem bērniem, izņemt pirmo. Ģimenes valsts pabalsts ir 22,76 eiro par otro bērnu, 34,14 eiro par trešo bērnu un 50,07 eiro par ceturto un nākamajiem bērniem. Lai mazinātu nabadzību ǵimenēs ar vairākiem apgādājamiem bērniem, sākot ar 2018. gadu, pie giimenes valsts pabalsta ir piemaksas par tiem bērniem, kuri nav sasnieguši 19 gadu vecumu un turpina mācìties. Ja ǵimenē ir divi šādi bērni, tad piemaksa ir 10 eiro, ja ğimenē ir trīs apgādājami bērni, piemaksa ir 66 eiro, un par katru nākamo apgādājamo bērnu tā pieaug par 50 eiro (VSAA, 2018).

Būtiski ir palielinātas iedzīvotāju ienākuma nodokḷa atlaides - no agrākiem 100 eiro par apgādībā esošu bērnu līdz 200 eiro pašlaik. Šo summu ir paredzēts pakāpeniski palielināt līdz 250 eiro 2020. gadā (Finanšu ministrija informācija, 2018). Saistībā ar nodokḷu reformu šo neapliekamo minimumu var saṇemt nevis kā algas pielikumu ik mēnesi, bet gan iesniedzot nodokḷu deklarācijas par iepriekšējo gadu, turklāt atlaidēm proporcionāli kvalificējas tikai par 1000 eiro zemākas mēnešalgas. Piemēram, ğimene ar diviem strādājošiem un diviem apgādājamiem bērniem (ja katrs vecāks saṇem līdz 500 eiro mēnesī), iesniedzot deklarāciju, var saņemt no valsts budžeta līdz 960 eiro gadā.

Būtiskās nodokḷa atlaides ir ieviestas nekustamā ìpašuma nodoklim daudzbērnu giimenēm. Tās var atškirties dažādās pašvaldībās, taču biežāk tās ir līdz 50\% par mājokli un līdz 90\% par zemi. Daudzbērnu gimene var gūt 50-500 eiro atlaides ik gadu atkarībā no īpašuma vērtības. Valsts atbalsta programma pirmā mājokḷa iegādei jaunajām ğimenēm tika uzsākta 2015. gada nogalē, un līdz 2017. gada beigām šo atbalstu ir saņēmušas ap 7300 gimeņu, kurās dzīvo 10500 bērnu (Ekonomikas ministrijas informācija, 2018). Mājokḷu iegādes atbalsta būtība ir ḷaut jaunajām ǵimenēm ņemt mājokḷa kredītu, 
nesakrājot aizdevuma pirmo iemaksu (nereti tā jākrāj 10-15 gadus). Valsts papildus aizdod šo pirmo iemaksu garantijas veidā, un, kaut arī ǵimeņu kopējās kredītsaistības palielinās, tām tomēr ir izdevīgāk ilgus gadus nevis īrēt dzīvokli, bet ar kredīta palīdzību apmaksāt sev piederošā īpašuma vērtību. Pagaidām šì palīdzība pieejama turīgākajām ğimenēm, kam vispār ir pieejami mājokḷu kredīti (2/3 saņēmēju koncentrējas Rīgā un Pierīgā). Turpmāk mājokḷu programma ir jāpaplašina, lai palīdzētu arī pieticīgāku mājokḷu pircējiem (sākot jau no 5 vai 10 tūkst. eiro).

Ne visi ǵimeņu atbalsta veidi tiek dotēti no valsts budžeta. Daudz var palīdzēt arī pašvaldības. Rīdziniekiem un Pierīgā dzīvojošiem problēma joprojām ir garās rindas uz pašvaldības bērnudārziem. Tiesību aktos noteikts, ka pašvaldības ir atbildīgas par bērnudārza pakalpojumu nodrošināšanu visiem tās teritorijā dzīvojošiem bērniem no pusotra gada vecuma. Tomēr daudzas pašvaldības šo normu nespēj izpildìt. Lai mazinātu tādu bērnu skaitu, kuriem kāds no vecākiem nevar atgriezties darbā, jo nav vietas pašvaldības bērnudārzā, sākotnēji tika ieviests valsts līdzmaksājums 140 eiro apmērā par tiem bērniem, kuri rindu dēl netiek pašvaldības bērnudārzos un kuru vecāki ir spiesti maksāt par dārgākiem privāto bērnudārzu pakalpojumiem. Vairākas pašvaldības, t. sk. Rīgas, pie šì līdzmaksājuma pierada kā pie ilgtermiņa dotācijas. Daḷēji tāpēc šāds līdzmaksājums tika pārtraukts. Pašlaik saskaṇā ar pašvaldību lēmumiem privāto bērnudārzu pakalpojumi rindā stāvošajiem tiek segti pilnībā vai daḷēji. Rīgas dome nesen šâdos gadījumos palielināja savu dotāciju līdz 231 eiro (Rīgas domes informācija, 2018). Tas gan nesedz maksājumus par privāto bērnudārzu pakalpojumiem. Aptuveni par katru ceturto Rīgas bērndārznieku vecāki ik mēnesi ir spiesti maksāt apmēram par 100 eiro vairāk nekā tad, ja nebūtu rindu uz pašvaldības bērnudārziem.

Pirms izmaiņām brīvpusdienas valsts apmaksāja tikai pirmo klašu skolēniem. Pakāpeniski tās sāka apmaksāt arī 2., 3. un 4. klašu skolēniem, bet vecāko klašu skolēniem brīvpusdienas sākušas apmaksāt arī daudzas pašvaldības, t. sk. Rìgas pašvaldība. Arī sabiedriskais transports skolēniem līdz 11. klasei ir par brīvu Rīgā un dažās citās pašvaldībās. Pašvaldības dotē arī bērnu un jauniešu piedalīšanos dažādās ārpusskolas nodarbībās un interešu pulciṇos.

Bez minētajiem atbalsta veidiem ir vēl arī citi, piemēram, pabalstu dubultošana aizbildņiem un adoptētājiem, kā arī apgādnieka zaudētājiem. No 25\% lìdz 50\% ir palielināts ikgadējā transportlīdzekḷa ekspluatācijas nodokḷa atvieglojums daudzbērnu ǵimenēm. Vairumam tā saņēmēju tas nozīmē par 2040 eiro mazāku maksājumu. Vairākas ministrijas regulāri sveic giimenei draudzīgus komersantus un ǵimenei draudzīgākās pašvaldības. Tas rosina darba devējus un pašvaldības paplašināt atbalstu gimenēm, lai stimulētu dzimstību un palielinātu iedzīvotāju skaitu. 


\section{Secinājumi un ieteikumi}

Relatīvi nelielais sieviešu skaits vecumā no 20 līdz 34 gadiem Latvijā negatīvi ietekmēs dzimušo skaitu nākotnē. Demogrāfiskajā politikā ir jāiekḷauj dzimstības veicināšana kā viena no galvenajām prioritātēm tautas ilgtspējīgas ataudzes nodrošināšanai.

Dzimstības veicināšanai demogrāfiskajā politikā ir vairāki virzieni un rīcības instrumenti. Svarīgi ir ilgtermiṇa atbalsta pasākumi ǵimenes ienākumu līmeņa saglabāšanai pirms dzemdībām un pēcdzemdību periodā. Šim atbalstam ir jārada drošības sajūta, plānojot nākamo bērnu dzimšanu. Nozīmīgs rīcībpolitikas virziens ir atbalsts nabadzības mazināšanai ǵimenēm ar augstu nabadzības risku - daudzbērnu ğimenēm un vientuḷiem vecākiem ar bērniem.

Darba devējiem ir vairāk jāiesaistās tādu aktivitāšu nodrošināšanā, kuras var veicināt darbinieku darba pienākumu un ǵimenes apstākḷu līdzsvarošanu. Aktivitāte "Ģimenei draudzīgs komersants" šai ziṇā ir labs piemērs. Līdzīgu aktivitāšu popularizēšana var mainīt darba devēju attieksmi, l̦aujot attīstīt sociāli atbildīgu uzṇēmējdarbību. Būtu minamas 2 iniciatīvas: elastīga darba grafika un attālināta darba veicināšana, ja to piel̦auj darba specifika.

Svarīgs rīcībpolitikas virziens, kas var sekmēt tautas ataudzi, ir izpratnes veicināšana par dzimumu līdztiesību ǵimenēs. Dzimumu līdztiesībai ir būtiska ietekme uz ǵimeņu stabilitāti un vecāku ieguldījumu bērnu audzināšanā.

Jāturpina ieviest valsts atbalsta pasākumus neauglības ārstēšanai un jāatbalsta pirmā mājokḷa iegāde. Mājokḷa iegādes programmā jāḷauj piedalīties ne tikai vecākiem ar bērniem, bet arī jaunajiem speciālistiem bez bērniem, tas palīdzētu risināt mājokḷa jautājumu un sekmētu jauno vecāku un bērnu dzīves apstākḷu uzlabošanos.

\section{Literatūra un avoti}

Āboliṇa, L. (2016) Ģimene un tās atbalsta politikas attistỉba Latvijā (1990-2015). Promocijas darbs. Rīga: Latvijas Universitāte [https://dspace.lu.lv/dspace/bitstream/handle/7/31863/298 54487-Abolina_Liga_la10049.pdf (15.09.2017.)].

Āboliņa, L. (2016) Ģimenes valsts politika - mērķi un izaicinājumi [http://www.pkc.gov.lv/sites/default/files/inline-files/14042016\%20_LM_par_gimenes_politiku.pdf (15.09.2017.)].

Eglìte, P. u.c. (2013) Tautas ataudzi ietekmējošo faktoru izpēte [http://www.lm.gov.lv/upload/berns_gimene/gala_zin13012014.pdf (15.09.2017.)].

Ekonomikas ministrijas informācija [https://em.gov.lv/lv/jaunumi/18176-no-marta-valstsgarantijas-majokla-iegadei-pieejamas-ari-jaunajiem-specialistiem (07.08.2018.)].

Eurostat datubāze [https://ec.europa.eu/eurostat/data/database (07.08.2018.)].

Finanšu ministrijas infografika [http://www.fm.gov.lv/files/files/Atalgojums\%20-\%20gimene\%20ar\%202\%20berniem.png (07.08.2018.)].

GFK Custom Research Baltic (2013) Trūcīgo mājsaimniecību ar bērniem raksturojums. Sākotnējais izvērtējums [http://www.lm.gov.lv/upload/petijumi/izvertejums_trucigas.pdf (15.09.2017.)]. 
G̦imenes valsts politikas pamatnostādnes 2011.-2017. gadam [http://www.lm.gov.lv/upload/ berns_gimene/lmpamn_200111_gvp.pdf (15.09.2017.)].

Kārkliņa, I. (2016) Status Quo tautas ataudzē: NAP2020 mērķu sasniegšanas progress [https:// www.pkc.gov.lv/sites/default/files/inline-files/DLC_prezentacija_PKC_14042016_0.pdf (15.09.2017.)].

Korporatīvās ilgtspējas un attīstības institūts [https://www.incsr.eu/novertejumi/ilgtspejasindekss/ (15.09.2017.)].

Latvijas ilgtspējīgas attīstības stratēgija līdz 2030. gadam [http://www.varam.gov.lv/lat/ $\mathrm{pol} / \mathrm{ppd} /$ ?doc $=13857$ (15.09.2017.)].

Latvijas Nacionālais attīstības plāns 2014.-2020. gadam [http://www.varam.gov.lv/lat/pol/ ppd/ilgtsp_att/?doc $=13858$ (15.09.2017.)].

Mežs, I. (2014) Demogrāfijas atbalsta politiku salidzinājums Latvijā un Igaunijā [https://www. bvef.lu.lv/fileadmin/user_upload/lu_portal/projekti/bvef/konferences/LU_73_konference/Demografija/Mezs.pdf (15.09.2017.)].

Mileiko, I. u. c. (2017) Elastīga bērnu uzraudzïbas pakalpojuma nodrošināšana darbiniekiem, kas strādā nestandarta darba laiku [http://www.lm.gov.lv/upload/projekts/faili/13_nodevums.pdf (15.09.2017.)].

Pārresoru koordinācijas centrs (PKC) (2012). Latvijas ilgtspējīgas attīstības stratēǵijas līdz 2030. gadam īstenošanas uzraudzības zinojums [https://www.pkc.gov.lv/sites/default/ files/inline-files/PKC_Zinojums_LIAS_0.pdf (15.09.2017)].

Putniņa, A. u.c. (2015) Reǵistrētas un nereǵistrētas kopdzìves faktoru salìdzinoša analize [http://www.antropologija.lu.lv/zinas/t/34493/ (15.09.2017.)].

Rastrigina, O. (2015) Dzimumu lidztiesỉbas politika Latvijā [http://www.europarl.europa.eu/ RegData/etudes/IDAN/2015/510008/IPOL_IDA(2015)510008_LV.pdf (15.09.2017.)].

Rīgas domes informācija [https://pasvaldiba.riga.lv/NR/exeres/10C396AF-E3B3-48BF-A2F0799AF6AC94F3.htm?WBCMODE = PresentationUnpublished (07.08.2018.)].

Saeimas Preses dienests. I. Parādnieks: "Māras solis" - visaptveroša valsts atbalsta programma g̊imenēm ar bērniem, kas veidojama un realizējama līdz Latvijas simtgadei [http:// www.saeima.lv/lv/aktualitates/saeimas-zinas/23277-i-paradnieks-maras-solis-visaptverosa-valsts-atbalsta-programma-gimenem-ar-berniem-kas-veidojama-un (15.09.2017.)].

Salaka, S. u. c. (2014) Izpētes ziñojums: daudzbērnu ǵimeņu situācija mūsdienu Latvijā [http:// titania.saeima.lv/livs/saeimasnotikumi.nsf/0/5f1bd5a948d699c2c2257c24002ac867/\$ FILE/Daudzbernu_gimenu_situacija_APTAUJA_final\%20copy.pdf (15.09.2017.)].

Sedlenieks, K. u.c. (2017) Tētis uz 13\%. Latvijas tēvi pēc škiršanās [https://www.lsm.lv/ raksts/dzive--stils/vecaki-un-berni/lsm-infografika-ka-skirtie-tevi-tiesajas.a248936/ (15.09.2017.)].

Seņkāne, E. Laulātības un dzimstības rādìtāji Latvijā pieaug [http://ec.europa.eu/eurostat/ statistics-explained/index.php/Marriages_and_births_in_Latvia/lv (15.09.2017.)].

Tirgus un sabiedriskās domas pētījumu centrs SKDS (2008) Demogrāfija un gimenes stāvoklis Latvijā. Iedzīvotāju aptauja [http://www.lm.gov.lv/upload/berns_gimene/bernu_tiesibas/demogr_gim_lv.pdf (15.09.2017.)].

Uibu, J. (2013) Igaunijas demogrāfiskās mācības jeb ko var darìt efektīvāk: iedzīvotāji, dzimstïbas koeficients, vēsturisko notikumu ietekme un apdzīvotïbas politika Igaunijā pēdējos 95 gados [http://www.saeima.lv/documents/27eaa41603671d26c08bcc66b4064560fe84 7f1d (15.09.2017.)].

United Nations (2013) World Population Policies [http://www.un.org/en/development/desa/ population/publications/pdf/policy/WPP2013/wpp2013.pdf (15.09.2017.)]. 
VSAA (2018) [https://www.vsaa.lv/pakalpojumi/vecakiem/gimenes-valsts-pabalsts/; [https:// www.vsaa.lv/pakalpojumi/vecakiem/berna-kopsanas-pabalsts/ (07.08.2018.)].

Vides ministrija (2002) Latvijas nacionālais ziņojums "Rio + 10" ANO Vides un attīstības konferencei Johannesburgā [http://providus.lv/article/latvijas-nacionalais-zinojumsrio-10-ano-vides-un-attistibas-konferencei-johannesburga (15.09.2017.)].

Zvidriņš, P. (zin. red.) (2001) Demogrāfisko terminu skaidrojošā vārdnīca. Rīga: LU.

Zvidriņš, P. (2012) Demographic Development in the Baltic Sea Region [http://www.lza.lv/ LZA_VestisA/66_5-6/5_Peteris\%20Zvidrins.pdf (15.09.2017.)].

Zvidriņš, P., Eglīte, P. (1990) Demogrāfiskā situācija un demogrāfiskā politika Latvijā. LPSR ZA Vēstis, 5 (514): 66-74. 